\title{
Predictive Role of Cognitive Flexibility and Self-Control on Social Media Addiction in University Students
}

\author{
Mehmet Enes Sağar ${ }^{1}$ \\ ${ }^{1}$ Department of Child Care and Youth Services, Çay Vocational School, Afyon Kocatepe University, Afyon, \\ Turkey \\ Correspondence: Mehmet Enes Sağar, Department of Child Care and Youth Services, Çay Vocational School, \\ Afyon Kocatepe University, Afyon, Turkey. E-mail: mehmetenes15@gmail.com
}

Received: October 11, 2020

doi:10.5539/ies.v14n4p1

\author{
Accepted: December 15, $2020 \quad$ Online Published: March 10, 2021 \\ URL: https://doi.org/10.5539/ies.v14n4p1
}

\begin{abstract}
The aim of this study is to examine how cognitive flexibility and self-control variables predict the social media addiction levels of university students. Relational model-based screening conducted in the 2020-2021 academic year. The research group studying this study in different universities in Turkey, 230 (47\%) were male and 259 (53\%) were female, the total of 489 university students. The average age of the research group is 20.21 . Social Media Addiction Scale, Cognitive Flexibility Inventory, Self-Control Scale and Personal Information Form were used as data collection tools in the study. The data obtained from the research were analyzed by using the stepwise regression analysis method from multiple linear regression analysis. As a result of the research; it was revealed that cognitive flexibility and self-control variables significantly predicted social media addiction.
\end{abstract}

Keywords: university, students, cognitive flexibility, self-control, social media addiction

\section{Introduction}

With the increase of digitalization and electronic devices, fast and easy access to the internet, activities such as information, entertainment, communication, shopping, business, and learning are becoming widespread (Goel, Subramanyam, \& Kamath, 2013; Rüzgar, 2005; Szczygieł \& Podwalski, 2020). With the spread of the internet, almost revolutionary technological advances, the use of social media (Instagram, Facebook, Twitter, YouTube, etc.) is almost inevitable and extremely popular in terms of social interaction (Akakandelwa \& Walubita, 2018; Berryman, Ferguson, \& Negy, 2018). Social media are relatively inexpensive and widely accessible electronic tools with functions such as communicating and interacting, expressing ideas and comments, sharing and discussing, broadcasting and accessing information (Edosomwan, Prakasan, Kouame, Watson, \& Seymour, 2011; Siddiqui \& Singh, 2016; Griffiths, Kuss, \& Demetrovics 2017; Zamri, Zaihan, \& Samat, 2018). In addition to the positive functions of social media when used normally and when necessary, it has some negative effects such as excessive and persistent use. Social media addiction draws attention as one of these negative effects (Andreassen, 2015).

There is no clear definition for social media addiction. However, while it is discussed whether excessive behaviors in behavioral addictions (such as internet, video game playing, exercise, sex, etc.) can be considered as real addictions, the same discussion continues for social media addiction (Griffiths, 2013). Although DSM 5 includes a diagnosis of 'Internet Gaming Disorder', it is also an important reason that there is no definition for social media addiction (APA, 2013). Although there is no clear definition, as Young (2009) stated, compliance with addiction criteria such as neglect of life, escape, mental preoccupation, tolerance, mood-changing experiences and hiding addictive behavior is present in people who use social media excessively (Kuss \& Griffiths, 2011). Social media addiction, which is considered as a type of internet addiction, means that individuals spend too much time using online social networks excessively, experience compulsive behaviors with the desire to be informed about a subject immediately, and use social media in an excessive and unreasonable way by negatively affecting other areas of daily life (Griffiths, 2000, 2012, 2013; Şahin, 2017). In this context, it can be stated that more research is needed on social media addiction disorder due to the uncertainties regarding the social media issue and the problems it causes.

The pleasant and exciting social media environment, especially among the young population, is alarming due to its excessive use, and its largest users are especially university students and are considered to be a vulnerable group 
against social media addiction (Akakandelwa \& Walubita, 2018; Mahamid \& Berte, 2019; Alaika, Doghmi, \& Cherti, 2020; Szczygieł \& Podwalski, 2020). Especially the fact that university students spend excessive time on social media and remain vulnerable to the risk of addiction can be a major threat to their mental health. Therefore, it is thought that studies on variables that may be related to social media addiction of university students will contribute to both better understanding of social media addiction and behavioral addiction and mental health studies.

As a result of the literature review, it was seen that the problem of social media addiction among university students was associated with variables such as depression, anxiety, loneliness, stress, negative relationship between work-family balance, self-esteem, interaction anxiety (Özgür, 2013; Aydoğan \& Büyükyılmaz, 2017; Zivnuska, Carlson, Carlson, Harris, \& Harris, 2019; Haand \& Shuwang, 2020; Nguyen, Lin, Rahman, Ou, \& Wong, 2020; Hawi \& Samaha, 2016; Savci \& Aysan, 2016). In line with the existing studies, it is very important to understand the factors that cause social media addiction and the results that develop due to these factors and to offer solutions for them. In this study, the predictive role of cognitive flexibility and self-control on social media addiction was examined in university students.

Cognitive flexibility is that individuals are aware of their alternatives to any situation, desire to adapt to the situations they encounter, and are flexible in a self-sufficient position (Martin \& Anderson, 1998). Cognitive flexibility consists of individuals' desire to be flexible. Individuals who provide possible adjustments due to situational factors have more cognitive flexibility than those who give only one correct or appropriate behavioral response (Martin \& Rubin, 1995). Cognitive flexibility is the ability of individuals to create alternatives by putting forward options. Tendency to perceive difficult situations as controllable; it can be evaluated in three dimensions as the ability to perceive many alternative explanations for life events and human behavior and the ability to produce many alternative solutions to difficult situations (Dennis \& Vande Wall, 2010). Cognitive flexibility in general; it can be evaluated as the ability of individuals to adapt to situations, their ability to switch from one thought to another, or their ability to approach various problems with different strategies (Stevens, 2009). In this context, cognitive flexibility can be expressed as offering different solution alternatives to problems by evaluating the situations encountered from different aspects.

The other concept examined in this study is self-control. Self-control is a skill that expresses the regulation of physical and emotional responses of individuals and not acting impulsively by delaying their instant gratification (Rosenbaum, 1980). Self-control is the capacity of individuals to change and adapt themselves in order to achieve a more ideal harmony between themselves and the world (Duyan, Gülden, \& Gelbal, 2012). It is also considered as the successful invalidation of individuals' impulses (Baumeister, Bratslavsky, Muraven, \& Tice, 1998). Self-control is the ability of individuals to suppress or change their internal impulses and to divide unwanted behavioral orientations and avoid doing them (Tangney, Baumeister, \& Boone, 2004). The use of cognition and "self-expressions" to control physiological and emotional responses in order to enable individuals to apply self-control methods and evaluate their individual tendencies in solving behavioral problems, the application of problem solving strategies, the ability to delay instant gratification, and perceived self-efficacy (Rosenbaum, 1980). In this respect, it can be evaluated as the capacity of self-control to align individuals' behaviors with their own intentions in response to their impulses. For example, an individual's resistance to smoking despite a strong desire to smoke may be an example (Henden, 2008). In this context, self-control can be expressed as self-discipline of individuals against their desired impulses. In the context of the information obtained from the literature, it is thought that it is very important to know whether they show a significant predictor of the social media addiction variable with cognitive flexibility in parallel with self-control.

In the literature review on social media addiction, it was observed that there are studies examining social media addiction with different variables. However, there is no study examining social media addiction together with self-control and cognitive flexibility. Therefore, this study is considered valuable and important in terms of psychological counseling. In this study, do the variables of cognitive flexibility and self-control significantly predict the social media addiction levels of university students?" The answer to the question was sought. Based on this problem statement, the sub-problems of this research are expressed as follows:

a) How much do cognitive flexibility and self-control variables together predict the social media addiction levels of university students?

b) What are the powers of each of the variables of cognitive flexibility and self-control in predicting the social media addiction levels of university students?

c) What is the order of importance in predicting the social media addiction levels of the variables of cognitive flexibility and self-control? 


\section{Method}

\subsection{Research Model}

The relational scanning model was used in the research. This model is a research model for determining the existence or degree of co-change between two or more variables. This model is a model for determining whether the variables change together and if there is a change, how it happens (Karasar, 2016).

\subsection{Research Group}

In this study, the research group studying in different universities in the 2020-2021 academic year in Turkey 230 $(47 \%)$ were male, $259(53 \%)$ of a total of 489 students, including girls. The distribution of the research group in terms of gender is given in Table 1. The age range of the research group is between 18-25; the average age is 20.21.

Table 1. Distribution of research group by gender

\begin{tabular}{ccc}
\hline Gender & $\mathrm{N}$ & $\%$ \\
\hline Male & 230 & 47 \\
Female & 259 & 53 \\
Total & 489 & 100 \\
\hline
\end{tabular}

\subsection{Data Collection Tools}

\subsubsection{Social Media Addiction Scale (SMAS)}

This scale, which was created to determine the social media addiction levels of university students, is 5-point Likert type and 26 items. The scale has three sub-dimensions: "Difficulty of Control and Deprivation", "Impaired Functioning" and "Social Isolation". The higher the score on the scale, the higher the level of addiction to social media. The correlation between the scale's criterion validity and the problematic internet use scale was found to be 0.75. Cronbach alpha reliability coefficient of the scale; It was calculated as .95 for the whole scale, .92 for the "Difficulty and Deprivation" sub-dimension, .91 for the "Deterioration in Functioning" sub-dimension, and .81 for the "Social Isolation" sub-dimension (A ğyar Bakır \& Uzun, 2018). In this study, the Cronbach alpha reliability coefficient for the whole scale was determined to be .94 .

\subsubsection{Cognitive Flexibility Inventory (CFI)}

Adaptation of this scale developed by Dennis and Vander Wal (2010) to Turkish, validity and reliability studies were carried out by Sapmaz and Doğan (2013). The scale is 5-point Likert type and 20 items; Items 2, 4, 7, 9, 11, 17 are scored in reverse. The scale has two sub-dimensions as "alternatives" and "control". High scores from the scale indicate high cognitive flexibility. In the Turkish adaptation of the scale, the validity study was performed with criterion-related validity, exploratory and confirmatory factor analysis methods; Its reliability was evaluated by Cronbach's alpha internal consistency and test-retest methods. Cronbach alpha reliability coefficient of the scale; It was determined as .90 in the whole scale, .90 in the "alternatives" sub-dimension and .84 in the "control" sub-dimension. In terms of test-retest reliability coefficient, it was determined that the scale was .75 in the whole scale, .78 in the "alternatives" sub-dimension and .73 in the "control sub-dimension (Sapmaz \& Doğan, 2013). In this study, the Cronbach alpha reliability coefficient for the whole scale was determined to be .84 .

\subsubsection{Self-Control Scale (SCS)}

Developed by Rosenbaum (1980), this scale was adapted into Turkish by Duyan, Gülden \& Gelbal (2012). The scale is 6-point Likert type and 36 items. The scale has three sub-dimensions: "Experiential Self-Control", "Regenerative Self-Control" and "Restorative Self-Control". High scores from the scale indicate higher self-control level; low scores mean that the level of self-control is low. The reliability of the scale was evaluated by Cronbach alpha internal consistency and test-retest methods. Test-retest method correlation values were 0.816 in "Experiential Self-Control" dimension; It was determined as 0.733 in "Regenerative Self-Control" dimension, 0.717 in "Restorative Self-Control" dimension and 0.809 in the whole Self-Control Scale. Cronbach's alpha reliability coefficient of the scale is .83 in the "Experiential Self-Control" sub-dimension; it was calculated as 0.75 in the "Regenerative Self-Control" sub-dimension, .72 in the "Restorative Self-Control" sub-dimension, and 0.80 in the entire scale (Duyan, Gülden, \& Gelbal, 2012). In this study, the Cronbach alpha reliability coefficient for the whole scale was determined to be .86 .

\subsubsection{Personal Information Form}

This form has been prepared by paying attention to the confidentiality principle in order to learn the personal 
information of university students.

\subsection{Collection of Data}

In the study, it was first approved by the Ethics Committee of Afyon Kocatepe University Social and Human Sciences Scientific Research and Publication Ethics Committee (Date of Decision: 08.02.2021; Meeting: 03; Number of Documents: 5709). Later, the research data used in this study were collected online via Google Form. Data collection tools were prepared on Google Form and university students were invited to the research via e-mail. Informed consent was obtained from the students for the participation of volunteers in the study. During the data collection process, students were informed considering the privacy policy. The online data collection process was completed in approximately ten days.

\subsection{Data Analysis}

In order to determine the suitability of the data obtained from the research in terms of multiple linear regression analysis, the normality and linearity of the data sets were examined. Whether there are extreme values that make normality (multivariate) and linearity assumptions difficult is examined in the context of mahalanobis distance (13.82), cook's $($ Cook '<1) and leverage values $(.000-.020)$. The data sets in the study were examined with kurtosis, skewness values $(+1 /-1)$, scatter and histogram graphics. As a result of these examinations, the data belonging to 23 people were excluded from the data set because they had extreme values at a level that would affect the data analysis. In addition to providing the linearity and normality conditions of the data sets, it was seen that the sample size was appropriate in terms of the number of predictive variables. Another assumption of the multiple linear regression analysis is that there is no high correlation coefficient between the predictor variables. At this point, it was determined that there was no correlation value over .80, which could be defined as multiple connectivity between predictive variables (Table 3.), tolerance values were higher than .20, VIF values were less than 10 and CI values were less than 30. It was determined that the Durbin-Watson value was between 1-3 $(\mathrm{DW}=1.98)$ in terms of the condition that the errors are independent and it did not cause any problems. In the context of these investigations, it has been determined that the data are suitable for multiple linear regression analysis. The data obtained from the research were analyzed with the method of stepwise regression analysis from multiple linear regression analysis. The study was based on .05 significance level (Akbulut, 2010; Büyüköztürk, 2011).

\section{Findings}

In the findings part of the research; First, the arithmetic mean and standard deviation values for social media addiction, cognitive flexibility and self-control scores of the research group, then the simple correlation analysis coefficients for the variables, and finally the multiple linear regression analysis (stepwise) results for the prediction of social media addiction.

The arithmetic mean and standard deviation values of the research group regarding social media addiction, cognitive flexibility and self-control scores are given in Table 2.

Table 2. Arithmetic mean and standard deviation values

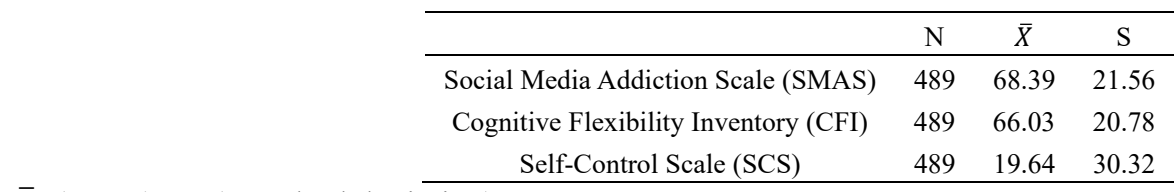

$\bar{X}$ : (Mean); S: (Standard deviation).

When Table 2 is examined, the arithmetic means of the research group; social media addiction $(\bar{X}=68.39)$, cognitive flexibility $(\bar{X}=66.03)$ and self-control $(\bar{X}=19.64)$.

Relationships between social media addiction, cognitive flexibility and self-control of university students were examined by simple correlation analysis method and the results obtained are given in Table 3 . 
Table 3. Simple correlation analysis coefficients for variables

\begin{tabular}{cccc}
\hline & SMAS & CFI & SCS \\
\hline Social Media Addiction Scale (SMAS) & 1 & & \\
Cognitive Flexibility Inventory (CFI) & -.586 & 1 & \\
Self-Control Scale (SCS) & -.371 & .513 & 1 \\
\hline
\end{tabular}

When Table 3 is examined, it is seen that there is a significant negative relationship between social media addiction, cognitive flexibility and self-control; It was determined that there is a significant positive correlation between cognitive flexibility and self-control. In addition, when Table 3 is examined, it is seen that there is no correlation value above .80 , which can be defined as multiple connectivity between predictor variables. When the ANOVA table, which tests the relationship between the predictive variables of the stepwise regression analysis and the predicted variable, and the degree of explanation of the change in the predicted variable, was examined, it was found that the explained variance or the regression model was statistically significant (F1/487 = 254.80; F2/486 = 130.94; $\mathrm{p}<.01$ ). Accordingly, the predictive variables successfully performed the prediction process on the model.

Table 4. Stepwise multiple regression analysis results related to the prediction of social media addiction scale

\begin{tabular}{|c|c|c|c|c|c|c|c|c|c|c|}
\hline Model & & $\mathrm{JC}$ & $\mathrm{SC}$ & & & & & & & \\
\hline & $\mathrm{B}$ & Std. Error & Beta & $\mathrm{t}$ & Zero order & Partial & $\mathrm{R}$ & $\mathrm{R}^{2}$ & $\mathrm{~F}$ & $\mathrm{df}$ \\
\hline 1.(C) & 108.55 & 2.63 & & $41.16^{* *}$ & & & \multirow{2}{*}{$.586^{\mathrm{a}}$} & \multirow{2}{*}{.343} & \multirow{2}{*}{254.80} & \multirow{2}{*}{$1 / 487$} \\
\hline CFI & -.608 & .038 & -.586 & $-15.96^{* *}$ & -.586 & -.586 & & & & \\
\hline 2.(C) & 106.54 & 2.77 & & $38.36^{* *}$ & & & \multirow{3}{*}{$.592^{\mathrm{b}}$} & \multirow{3}{*}{.350} & \multirow{3}{*}{130.94} & \multirow{3}{*}{$2 / 486$} \\
\hline CFI & -.558 & .044 & -.537 & $-12.61^{* *}$ & -.586 & -.497 & & & & \\
\hline SCS & -.068 & .030 & -.095 & $-2.23^{*}$ & -.371 & -.101 & & & & \\
\hline
\end{tabular}

$* * \mathrm{P}<.01, * \overline{\mathrm{P}}<.05, \mathrm{C}:$ (Constant), UC: (Unstandardized Coefficients), SC: (Standardized Coefficients), CFI: (Cognitive Flexibility Inventory), SCS: (Self-Control Scale).

When Table 4 is examined, it is determined that cognitive flexibility and self-control variables are included in the process in the multiple linear regression analysis (stepwise) process, as they significantly predict social media addiction. When both beta and correlation (binary/partial) values were examined, it was determined that there was a significant negative relationship between the social media addiction variable and the variables of cognitive flexibility and self-control. Cognitive flexibility and self-control variables together explain $35 \%(\mathrm{R}=.592 ; \mathrm{R} 2$ $=.350 ; \mathrm{p}<.01)$ of the total variance related to internet addiction of university students.

The beta coefficient of the cognitive flexibility variable examined in the first step of the stepwise regression analysis in predicting social media addiction is -.586. It was determined that the t-test result regarding the significance of the beta coefficient was significant $(\mathrm{t}=-15.96 ; \mathrm{p}<.01)$. Cognitive flexibility alone explains approximately $34 \%$ of social media addiction $(\mathrm{R}=.586$; $\mathrm{R} 2=.343)$.

In the second step of the stepwise regression analysis, besides the cognitive flexibility variable, the self-control variable also entered the model. When other variables affecting social media addiction are kept constant, cognitive flexibility and self-control variables together explain $35 \%$ of social media addiction $(\mathrm{R}=.592 ; \mathrm{R} 2=.350)$. When the other variables in the model are kept constant, the beta coefficient of the cognitive flexibility variable is -.537; Beta coefficient of emotion self-control variable is -.095. It was determined that the results of the $t$ test regarding the significance of the beta coefficient were significant ( $\mathrm{tCFI}=-12.61 ; \mathrm{p}<.01, \mathrm{tSCS}=-2.23 ; \mathrm{p}<.05)$.

In the second step, when the beta coefficients of the variables included in the model and the significance of the beta coefficients were taken into account, it was seen that cognitive flexibility and self-control variables significantly predicted social media addiction. Considering the beta values of the variables in the model, it was determined that the variables of "cognitive flexibility" in the first place and "self-control" in the second place significantly predicted the social media addiction of university students. In other words, the relative importance of predictive variables on social media addiction is cognitive flexibility and self-control.

\section{Conclusion, Discussion and Suggestions}

As a result of the research, it was determined that there is a significant negative relationship between social media addiction and cognitive flexibility and self-control. In addition, as a result of this study, it was seen that 
cognitive flexibility and self-control variables were significant predictors of the social addiction variable. Cognitive flexibility and self-control variables together explained $35 \%$ of social addiction. It was determined that the variables of "cognitive flexibility" in the first rank and "self-control" in the second place significantly predicted the social addiction of university students.

Based on these results obtained from the research, although the changes and developments in technology and the internet field provide positive opportunities such as rapid access to socialization, communication and communication, it is obvious that there is a negative effect such as social media addiction. This situation poses a current problem especially for university students where social media is used popularly. The easy access of social media with technological tools increases their use of social media and by gaining repetitive dimensions in this use, young individuals are encouraged to problems such as social media addiction. Therefore, it is thought that knowing social media addiction and the variables associated with it is very important in terms of reducing and preventing this negative behavior.

In this study conducted with university students, it was determined that the cognitive flexibility variable in the first place significantly predicted social media addiction and there was a significant negative relationship between them. In other words, it can be said that as the level of cognitive flexibility increases in university students, the level of social media addiction decreases. In the study conducted by Peker and Çukadar (2016), the result that cognitive flexibility negatively predicts the attitude towards using social media supports the result of this study. In the literature, there is no study directly examining social media addiction and cognitive flexibility; However, the results of studies examining the relationship between smoking and Internet addiction types and cognitive flexibility are consistent with the results of this study (Nesic, Rusted, Duka, \& Jacksona, 2011; Şenyiğit \& Kıran, 2018). In addition, studies in the literature indicate that cognitive flexibility is associated with variables such as depression, resilience and coping styles, anxiety, social skills, social support and loneliness, stress, and academic achievement (Curran, 2018; Gündüz, 2013; Kercood, Lineweaver, Frank, \& Fromm, 2017; Soltani, Shareh, Bahrainian, \& Farmani, 2013; Turan, Durgun, Kaya, Ertaş, \& Kuvan, 2019). Additionally, Sapmaz and Doğan (2013) emphasized that individuals with a high level of cognitive flexibility are individuals who can make their own decisions, can look at events from different angles, have high self-esteem, have low levels of depression, are internally controlled and optimistic. Hill (2008) states that individuals with a high level of cognitive flexibility can use their abilities effectively and find more than one solution to problems. Cox (1980) states that individuals with a high level of cognitive flexibility can make easy changes, whereas individuals with a low level of cognitive flexibility have difficulty in making changes. In this context, it can be said that university students' having a high level of cognitive flexibility will contribute to their versatile thinking and experience change by offering different solutions to their problems. Therefore, it is thought that university students with high levels of cognitive flexibility can effectively combat various problems they encounter, including social media addiction.

According to the other result obtained from this study conducted with university students, it was determined that the self-control variable significantly predicted social media addiction of university students in the second place and there was a significant negative relationship between them. In other words, as the level of self-control decreases in university students, the level of social media addiction increases. In this case, it can be said that university students with a high level of self-control have less social media addiction problems. In the review of the literature, the result of the study conducted by Khan, Khan, and Moin (2021) supports the conclusion reached from this study that self-regulation plays a buffering role in reducing the negative effects of social media addiction on individuals' mental health and task performance. In the study conducted by Ekşi, Turgut, and Sevim (2019), the result that self-control has a high direct effect on social media addiction and that social media addiction develops in individuals with low self-control and general procrastination is consistent with the result of this study. In the study conducted by Firat (2017), it was found that there is a significant relationship between Facebook, a social media tool, and self-control. It has been pointed out that there is distracting content, limited self-control, notices and warnings on Facebook. These results also support these research results. In addition, there are studies in the literature examining the relationship between behavioral addiction areas such as social media addiction and self-control. Studies on game addiction have found a negative relationship between game addiction and self-control (Aksel \& Sarı, 2020; Kim, Namkoong, Ku, \& Kim, 2007). In studies on problematic, excessive use of the internet and internet addiction, it has been observed that individuals who use the internet dysfunctionally have low levels of self-control (Akkuş Çutuk, 2020; Blinka, Škařupová, Ševčíková, Wölfling, Müller, \& Dreier, 2014; Ismail \& Zawahreh, 2017; Yau, Potenza \& White, 2012). In this context, it can be said that university students, who are highly self-controlled, can protect themselves from the addictive effects of social media, and can use social media more consciously by disciplining themselves. It is thought that high level of self-control plays an 
important role in the coping of university students with problems such as social media addiction.

In line with this study, it can be said that university students with high levels of cognitive flexibility and self-control have lower levels of social media addiction. Based on this result, it is thought that studies aimed at increasing cognitive flexibility and self-control levels with university students can help them to be more resistant to social media addiction. In addition to the fact that this study reveals an important result of high cognitive flexibility and self-control in reducing social media addiction, the research group has limitations such as the variables examined with social media addiction, and only quantitative data. In this context, a similar research can be conducted on different research groups other than university students. The predictive effect of variables other than cognitive flexibility and self-control on social media addiction can be examined. The research can be conducted on a wider scale by adding other variables to cognitive flexibility and self-control variables. Studies that can increase the cognitive flexibility self-control levels of university students in preventing or reducing social media addiction can be included. Psychological counseling activities can be prepared and applied to help university students who encounter many problems such as social media addiction gain the skills of developing different solution options against their problems and to control themselves by organizing them.

\section{References}

Ağyar Bakır, B., \& Uzun, B. (2018). Sosyal medya bağımlılığı ölçeği’nin geliştirilmesi: Geçerlik ve güvenirlik çalışmaları. Addicta: The Turkish Journal on Addictions, 5(3), 507-525.

Akakandelwa, A., \& Walubita G. (2018). Students' social media use and its perceived impact on their Social Life: A Case Study of the University of Zambia. International Journal of Multi-Disciplinary Research, 2, 1-14.

Akbulut, Y. (2010). Sosyal bilimlerde SPSS uygulamaları. İstanbul: İdeal Kültür Yayıncılık.

Akkuş-Çutuk, Z. (2020). Üniversite öğrencilerinde özdenetim ile internet bağımlılığı ilişkisi. Trakya Eğitim Dergisi, 10(3), 854-863. https://doi.org/10.24315/tred.650932

Aksel, N., \& Sarı, E. (2020) Ortaokul öğrencilerinin dijital oyun bağimliliği, öz denetimi ve sosyal eğilimleri. Ordu Üniversitesi Sosyal Bilimler Araştırmaları Dergisi, 10(2), 436-444.

Alaika, O., Doghmi, N., \& Cherti, M. (2020). Social media addiction among Moroccan university students: A cross sectional survey. Pan African Medical Journal-One Health, 1(4), 1-12. https://doi.org/10.11604/pamj-oh.2020.1.4.21930

American Psychiatric Association, DSM-5. (2013). Diagnostic and statistical manual of mental disorders: $D S M-5^{\mathrm{TM}}$ (5th ed.). Washington, DC.

Andreassen, C. S. (2015). Online social network site addiction: A comprehensive review. Current Addiction Reports, 2, 175-184. https://doi.org/10.1007/s40429-015-0056-9

Aydoğan, D., \& Büyükyılmaz, O. (2017). The effect of social media usage on students' stress and anxiety: A research in Karabuk university faculty of business. International Journal of Multidisciplinary Thought, 6, 253-260.

Baumeister, R. F., Bratslavsky, E., Muraven, M., \& Tice, D. M. (1998). Ego depletion: Is the active self a limited resource? Journal of Personality and Social Psychology, 74(5), 1252-1265. https://doi.org/10.1037/0022-3514.74.5.1252

Berryman, C., Ferguson C. J., \& Negy C. (2018). Social media use and mental health among young adults. Psychiatric Quarterly, 89(2), 307-314. https://doi.org/10.1007/s11126-017-9535-6

Blinka, L., Škařupová, K., Ševčíková, A., Wölfling, K., Müller, K. W., \& Dreier, M. (2014). Excessive internet use in European adolescents: What determines differences in severity? International journal of public health, 60(2), 249-256. https://doi.org/10.1007/s00038-014-0635-x

Büyüköztürk, Ş. (2011). Sosyal Bilimler İçin Veri Analizi El Kitabı (15. Bask1). Ankara: Pegem Akademi Yayıncilik.

Cox, K. S. (1980). The effects of second-language study on the cognitive flexibility of freshman university students (Unpublished doctoral dissertation). The Ohio State University.

Curran, T. (2018). An actor-partner interdependence analysis of cognitive flexibility and indicators of social adjustment among mother-child dyads. Personality and Individual Differences, 126, 99-103. https://doi.org/10.1016/j.paid.2018.01.025

Dennis, J. P., \& Vander Wal, J. S. (2010). The cognitive flexibility inventory: Instrument development and 
estimates of reliability and validity. Cognitive Therapy and Research, 34(3), 241-253. https://doi.org/10.1007/s10608-009-9276-4

Duyan, V., Gülden, Ç., \& Gelbal, S. (2012). Özdenetim ölçeği: Güvenirlik ve geçerlik çalışması. Toplum ve Sosyal Hizmet Dergisi, 23(1), 23-38.

Edosomwan, S., Prakasan, S. K., Kouame, D., Watson, J., \& Seymour, T. (2011). The History of Social Media and Its Impact on Business. The Journal of Applied Management and Entrepreneurship, 16(3), 79-91.

Ekşi, H., Turgut, T., \& Sevim, E. (2019). Üniversite öğrencilerinde öz kontrol ve sosyal medya bağımlılı̆̆ ilişkisinde genel erteleme davranışlarının aracı rolü. Addicta: The Turkish Journal on Addictions, 6, 717-745. https://doi.org/10.15805/addicta.2019.6.3.0069

Firat, M. (2017). Relationship between self-control and Facebook use: Case of CEIT students. Educational Sciences: Theory \& Practice, 17, 1179-1201.

Goel, D., Subramanyam, A., \& Kamath, R. (2013). A study on the prevalence of inter-net addiction and its association with psychopathology in Indian adolescents. Indian Journal of Psychiatry, 55(2), 140-143. https://doi.org/10.4103/0019-5545.111451

Griffiths, M. D. (2000). Internet addiction: Time to be taken seriously? Addiction Research, 8(5), 413-418. https://doi.org/10.3109/16066350009005587

Griffiths, M. D. (2012). Facebook addiction: Concerns, criticism, and recommendations-A response to andreassen and colleagues. Psychological Reports, 110(2), 518-520. https://doi.org/10.2466/01.07.18.PR0.110.2.518-520

Griffiths, M. D. (2013). Social Networking Addiction: Emerging Themes and Issues. Journal of Addiction Research \& Therapy, 4(5), 1-2. https://doi.org/10.4172/2155-6105.1000e118

Griffiths, M. D., Kuss, D. J., \& Demetrovics, Z. (2014). Social networking addiction: An overview of preliminary findings. Behavioral 119-141. https://doi.org/10.1016/B978-0-12-407724-9.00006-9

Gündüz, B. (2013). Emotional intelligence, cognitive flexibility and psychological symptoms in pre-service teachers. Educational Research and Reviews, 8(13), 1048-1056. https://doi.org/10.1080/02673843.2020.1741407

Haand, R., \& Shuwang, Z. (2020). The relationship between social media addiction and depression: a quantitative study among university students in Khost, Afghanistan. International Journal of Adolescence and Youth, 25(1), 780-786.

Hawi, H., \& Samaha, M. (2016). The relations among social media addiction, self-esteem, and life satisfaction in university students. Social Science Computer Review, 35(5), 576-586. https://doi.org/10.1177/0894439316660340

Henden, E. (2008). What is self-control? Philosophical Psychology, 21(1), 69-90. https://doi.org/10.1080/09515080701874092

Hill, A. (2008). Predictors of relationship satisfaction: The link between cognitive flexibility, compassionate love and level of differentiation (Unpublished doctoral dissertations). California School of Professional Psychology, Alliant International University, San Diego.

Ismail, A. B., \& Zawahreh, N. (2017). Self-control and its relationship with the internet addiction among a sample of najran university students. Journal of Education and Human Development, 6(2), 168-174. https://doi.org/10.15640/jehd.v6n2a18

Karasar, N. (2016). Bilimsel Araştırma Yöntemi (31. Basım). Ankara: Nobel Akademik Yayıncılık.

Kercood, S., Lineweaver, T. T., Frank, C. C., \& Fromm E. D. (2017). Cognitive flexibility and its relationship to academic achievement and career choice of college students with and without attention deficit hyperactivity disorder. Journal of Postsecondary Education and Disability, 30(4), 327-342.

Khan, N. A., Khan, A. N., \& Moin, M. F. (2021). Self-regulation and social media addiction: A multi-wave data analysis in China. Technology in Society, 64, 1-10. https://doi.org/10.1016/j.techsoc.2021.101527

Kim, E. J., Namkoong, K., Ku, T., \& Kim, S. J. (2008). The relationship between online game addiction and aggression, self-control and narcissistic personality traits. European Psychiatry, 23(3), 212-218. https://doi.org/10.1016/j.eurpsy.2007.10.010 
Kuss, D. J., \& Griffiths, M. D. (2011). Online social networking and addiction-a review of the psychological literature. International Journal of Environmental Research and Public Health, 8(9), 3528-3552. https://doi.org/10.3390/ijerph8093528

Mahamid, F. A., \& Berte, D. Z. (2019). Social media addiction in geopolitically at-risk youth. International Journal of Mental Health and Addiction, 17(1), 102-111. https://doi.org/10.1007/s11469-017-9870-8

Martin, M. M., \& Anderson, C. M. (1998). The cognitive flexibility scale: Three validity studies. Communication Repots, 11(1), 1-9. https://doi.org/10.1080/08934219809367680

Martin, M. M., \& Rubin, R. B. (1995). A new measure of cognitive flexibility. Psychological Reports, 76(2), 623-626. https://doi.org/10.2466/pr0.1995.76.2.623

Nesic, J., Rusted, J., Duka, T. \& Jacksona, A. (2011). Degree of dependence influences the effect of smoking on cognitive flexibility. Pharmacology Biochemistry Behavior, 98(3), 376-384. https://doi.org/10.1016/j.pbb.2011.01.015

Nguyen, T. H., Lin, K-H., Rahman, F. F., Ou, J-P., \& Wong, W-K. (2020). Study of depression, anxiety, and social media addiction among undergraduate students. Journal of Management Information and Decision Sciences, 23(4), 284-303.

Özgür, H. (2013). Öğretmen adaylarının sosyal ağ bağımlılı̆̆ı, etkileşim kaygısı ve yalnızlık düzeyi arasındaki ilişkinin incelenmesi. International Journal of Human Sciences, 10(2), 667-690.

Peker, A., \& Çukadar, F. (2016). Bilişsel esneklik ile sosyal medyayi kullanmaya yönelik tutum arasindaki ilişkinin incelenmesi. Sakarya University Journal of Education, 6(2), 66-79. https://doi.org/10.19126/suje.03104

Rosenbaum, M. (1980). A schedule for assessing self-control behaviors: Preliminary findings. Behavior Therapy, 11(1), 109-121. https://doi.org/10.1016/S0005-7894(80)80040-2

Rüzgar, N. S. (2005). A research on the purpose of internet usage and learning via internet. The Turkish Online Journal of Educational Technology, 4(4), 27-32.

Şahin, C. (2017). The predictive level of social media addiction for life satisfaction: A study on university students. TOJET: The Turkish Online Journal of Educational Technology, 16(4), 120-125.

Sapmaz, F., \& Doğan, T. (2013). Bilişsel esnekliğin değerlendirilmesi: Bilişsel esneklik envanteri Türkçe versiyonunun geçerlik ve güvenirlik çalışmaları. Ankara Üniversitesi Eğitim Bilimleri Fakültesi Dergisi, 46(1), 143-161.

Savci, M., \& Aysan, F. (2016). Relationship between impulsivity, social media usage and loneliness. Educational Process: International Journal, 5(2), 106-115. https://doi.org/10.12973/edupij.2016.52.2

Şenyiğit, A., \& Kıran, B. (2018). Investigation of problematic internet use according to cognitive flexibility levels of high school students. International Journal of Eurasia Social Sciences, 10(35), 367-384.

Siddiqui, S., \& Singh, T. (2016). Social media its impact with positive and negative aspects. International Journal of Computer Applications Technology and Research, 5(2), 71-75. https://doi.org/10.7753/IJCATR0502.1006

Soltani, E., Shareh, H., Bahrainian, S. A., \& Farmani, A. (2013). The mediating role of cognitive flexibility in correlation of coping styles and resilience with depression. Pajoohandeh Journal, 18(2), 88-96.

Stevens, A. D. (2009). Social problem-solving and cognitive flexibility: Relations to social skills and problem behavior of at-risk young children (Unpublished doctoral thesis). Seattle Pacific University (UMI No. 3359050).

Szczygieł, K., \& Podwalski, P. (2020). Comorbidity of social media addiction and other mental disorders-An overview. Archives of Psychiatry and Psychotherapy, 4, 7-11. https://doi.org/10.12740/APP/122487

Tangney, J. P., Baumeister, R. F., \& Boone, A. L. (2004). High self-control predicts good adjustment, less pathology, better grades, and inter personal success. Journal of Personality, 72(2), 271-324. https://doi.org/10.1111/j.0022-3506.2004.00263.x

Turan, N., Durgun, H., Kaya, H., Ertaş, G., \& Kuvan, D. (2019). Hemşirelik öğrencilerinin stres durumları ile bilişsel esneklik düzeyleri arasındaki ilişki. Hemşirelik Akademik Araştırma Dergisi (JAREN), 5(1), 59-66.

Yau, Y. H., Potenza, M. N., \& White, M. A. (2012). Problematic internet use, mental health and impulse control in an online survey of adults. Journal of behavioral addictions, 2(2), 72-81. 
https://doi.org/10.1556/JBA.1.2012.015

Zamri, N. S., Zaihan, N. A., \& Samat, M. F. (2018). A review on social media usage among students. Konvensyen Kebangsaan Pemimpin Pelajar, 1-5.

Zivnuska, S., Carlson, J. R., Carlson, D. S., Harris, R. B., \& Harris, K. J. (2019). Social media addiction and social media reactions: The implications for job performance. The Journal of Social Psychology, 159(6), 746-760. https://doi.org/10.1080/00224545.2019.1578725

\section{Copyrights}

Copyright for this article is retained by the author(s), with first publication rights granted to the journal.

This is an open-access article distributed under the terms and conditions of the Creative Commons Attribution license (http://creativecommons.org/licenses/by/4.0/). 